\title{
PREDICTION OF AMPUTATION AFTER SEVERE LOWER LIMB TRAUMA
}

\author{
PETER A. ROBERTSON
}

From Christchurch Public Hospital, New Zealand

The Mangled Extremity Severity Score was applied to 152 patients with severely injured lower limbs. All cases with a score of seven or more required amputation; some with scores of less than seven eventually came to amputation. These observations are discussed.

Advances in techniques of repair of bone, blood vessels, nerves and other soft tissues make possible the preservation of severely injured lower limbs, but the resultant leg may function less well than a prosthesis. Preservative surgery is costly in economic and social terms and the prolonged period of rehabilitation significantly reduces the chances of the patient ever returning to productive work (Hansen 1987).

The Mangled Extremity Severity Score (MESS) was developed in Seattle (Johansen et al 1990), based on both

Table I. Mangled Extremity Severity Score (MESS)

\begin{tabular}{ll}
\hline & Score \\
\hline $\begin{array}{l}\text { Skeletal/soft-tissue injury } \\
\text { low energy (stab; simple fracture; civilian gunshot wound) }\end{array}$ & 1 \\
medium energy (open or multiple fractures, dislocation) & 2 \\
high energy (shotgun; military gunshot wound, crush injury) & 3 \\
very high energy (as above, plus gross contamination, & 4 \\
soft-tissue avulsion) & \\
Limb ischaemia & \\
pulse reduced or absent but normal perfusion \\
pulseless; paraesthesiae; reduced capillary refill \\
cool, paralysed, insensate, numb \\
$\begin{array}{l}\text { (score doubled for ischaemia longer than six hours) } \\
\text { Shock }\end{array}$ & 1 \\
systolic BP maintained above 90 mmHg & 3 \\
transient hypotension & \\
persistent hypotension & \\
Age (years) & 0 \\
$<30$ & 2 \\
30 to 50 & \\
$>50$ & 1 \\
\hline
\end{tabular}

P. A. Robertson, FRACS, Orthopaedic Surgeon

The Spine Institute of New England, 2 Hurricane Lane, PO Box 1043, Williston, Vermont 05495, USA

(C) 1991 British Editorial Society of Bone and Joint Surgery

$0301-620 X / 91 / 5193 \$ 2.00$

J Bone Joint Surg [Br] 1991 ; 73-B : 816-8. retrospective and prospective analysis of admission data of patients with severe lower limb injuries.

Four variables determining skeletal and soft-tissue injury, limb ischaemia, surgical shock, and the age of the

Table II. Delayed amputation for trauma in 65 patients

\begin{tabular}{|c|c|c|c|c|}
\hline \multirow{3}{*}{$\begin{array}{l}\text { Delay in } \\
\text { amputation }\end{array}$} & \multicolumn{2}{|c|}{ MESS (number of patients) } & & \\
\hline & \multirow{2}{*}{$\begin{array}{l}>7 \\
10\end{array}$} & \multirow{2}{*}{$\begin{array}{l}<7 \\
20\end{array}$} & \multicolumn{2}{|c|}{ Reason for amputation } \\
\hline & & & $\begin{array}{l}\text { Necrosis } \\
\text { Infection } \\
\text { Loss of function } \\
\text { Not known }\end{array}$ & $\begin{array}{r}20 \\
5 \\
1 \\
4\end{array}$ \\
\hline 1 to 2 months & 3 & 3 & $\begin{array}{l}\text { Necrosis } \\
\text { Infection } \\
\text { Not known }\end{array}$ & $\begin{array}{l}2 \\
3 \\
1\end{array}$ \\
\hline 2 to 6 months & 1 & 5 & $\begin{array}{l}\text { Necrosis } \\
\text { Infection } \\
\text { Loss of function }\end{array}$ & $\begin{array}{l}1 \\
3 \\
2\end{array}$ \\
\hline$>6$ months & 2 & 21 & $\begin{array}{l}\text { Necrosis } \\
\text { Infection } \\
\text { Loss of function } \\
\text { Not known }\end{array}$ & $\begin{array}{r}1 \\
12 \\
8 \\
2\end{array}$ \\
\hline
\end{tabular}

Table III. Amputation after vascular reconstruction

\begin{tabular}{lll}
\hline & \multicolumn{2}{l}{ Number of patients (amputated) } \\
\cline { 2 - 3 } MESS & $\begin{array}{l}\text { ischaemia } \\
\text { ischaemia }\end{array}$ & $\begin{array}{r}>6 \text { hours } \\
\text { ischaemia }\end{array}$ \\
\hline$<7$ & $5(3)$ & $5(1)$ \\
$>7$ & $3(3)$ & $5(5)$ \\
\hline
\end{tabular}

patient are recorded on admission and a score is given for each (Table I). Assessment of limb ischaemia is based on the clinical assessment of pulse, perfusion, temperature, sensation and movement. The score is doubled if 
the time to restoration of perfusion exceeds six hours, because of the danger of irreversible tissue changes. Both the severity of hypotension and its duration affect the score. Increased age adversely affects the score because of the greater likelihood of other diseases.

When these four variables were assessed and a total score given, the experience in Seattle was that a score of seven or more predicted the need for amputation of the limb.

\section{PATIENTS AND METHODS}

During the last ten years adequate information was available for 152 patients who had suffered severe injuries to 164 lower limbs. They had required either vascular reconstruction, soft-tissue reconstruction by plastic surgeons, or had had major open fractures combined with other serious injuries; some had undergone traumatic amputation at the time of injury, or immediate amputation on admission to hospital.

The MESS was calculated from their status on admission as outlined in Table I. Assessment of skeletal and soft-tissue injury is clear-cut for low and medium energy injuries. For the higher energy injuries a crush injury meant that a significant operative debridement of devitalised muscle was required, and an avulsion injury implied that at least an entire muscle compartment was lost.

The subsequent course of treatment and the outcome for the limb were recorded.

\section{RESULTS}

Of the 164 severely injured limbs in this study, 121 eventually came to amputation. Twenty-six legs were amputated by the trauma, 30 patients had an immediate amputation on admission to hospital, because of the severity of the trauma, and delayed amputation was carried out in 65 .

The MESS for the patients who suffered traumatic amputation was seven or more except in one patient with severe visceral injuries. In this case, a viable foot was amputated on site to allow the patient to be removed from a vehicle.

Of the 30 patients who had immediate amputation on arrival at hospital, 25 had a MESS of seven or more, four scored six and one had a score of four.

Of the 65 patients undergoing delayed amputation, 16 had a MESS score of seven or more and the remainder scored less than seven (Table II). Necrosis or ischaemia was the usual cause for delayed amputation in the first month following injury. In those patients undergoing amputation after two months, infection and uselessness of the limb were the usual causes (Table II).

Forty-three limbs were salvaged or avoided amputation, and in these cases, no patient had a MESS of seven or more.
Vascular reconstruction was required in 18 patients. Eight had a MESS of seven or more and all came to amputation (Table III). Of the ten patients in whom the time to re-establishment of arterial supply was greater than six hours, six came to amputation. The four in whom the limb survived had adequate collateral circulation and scored only two points for ischaemia (doubled to four because it was prolonged beyond six hours). They were all young, showed an absence of shock, and had suffered from either low or medium energy injuries, keeping the MESS below seven. Of the two systemic parameters, the MESS was influenced by hypotension in 50 cases $(41.3 \%)$, and by age in 46 cases $(38 \%)$.

\section{DISCUSSION}

The advantages of an accurate system of objective scoring for severely injured limbs which would determine outcome are obvious. When the loss of a limb is predicted, immediate amputation would allow rehabilitation to begin at an early stage, with a shortened period of disability. But any scoring system that is a predictor of outcome, where one of the proposed treatments is amputation, must have a high degree of specificity.

In this study there were no false-positive results, indicating $100 \%$ specificity. However, the fact that many patients with a MESS of less than seven eventually underwent amputation, suggests that the method lacks sensitivity.

The grading system for skeletal and soft-tissue injury was simple to apply when scoring either one or two points but with high energy injuries, where three points are scored for a shotgun, military gunshot wound or crush injury, and four points for additional gross contamination or soft-tissue avulsion, the definitions are more subject to observer error, particularly when they are being used retrospectively, as in this study. Soft-tissue avulsion, which scores four points, was only diagnosed when at least an entire muscle compartment was involved. Traumatic amputation scores a MESS of seven by definition, due to the avulsion soft-tissue injury and to the vascular injury with its resultant extremity ischaemia.

The many references to firearm injuries reflect the North American origin of MESS. In our New Zealand study, only two patients suffered such injuries. The scoring of limb ischaemia from a combination of clinical signs gives a reasonable indication of outcome, but it alone is not an accurate predictor. Young patients may undergo periods of ischaemia exceeding six hours and require vascular reconstruction, yet in the presence of good collateral blood supply, and a low or medium energy injury, the leg can be saved.

The importance of re-establishing perfusion within six hours in the ischaemic, traumatised, lower limb where vascular reconstruction is required, cannot be overemphasised.

The measures of systemic shock and the age of the 
patient both add specificity to the mangled extremity severity score. This study confirms the significance of these variables in the outcome of the severely injured leg.

In managing tibial fractures with concurrent softtissue injuries of such severity that vascular reconstruction was required, Caudle and Stern (1987) found that the long-term results were poor. Most limbs eventually either required amputation, or functioned far less successfully than would a prosthesis. MESS provides clear guidelines for the management of these severely traumatised limbs. Absolute reliability is vital where one treatment option is amputation, and that specificity has been confirmed in our study.

No benefits in any form have been received or will be received from a commercial party related directly or indirectly to the subject of this article.

\section{REFERENCES}

Caudle RJ, Stern PJ. Severe open fractures of the tibia. $J$ Bone Joint Surg [ Am] 1987; 69-A :801-7.

Hansen ST Jr. Editorial. The type-IIIC tibial fracture: salvage or amputation. J Bone Joint Surg [Am] 1987; 69-A :799-800.

Johansen K, Daines M, Howey T, Helfet D, Hansen ST Jr. Objective criteria accurately predict amputation following lower extremity trauma. J Trauma 1990; 30:568-73. 